\title{
Effect of aging on the healing of colonic anastomoses in rats $^{1}$
}

\author{
Maria de Lourdes Pessole Biondo-Simões ${ }^{2}$, Sergio Ossamu Ioshii ${ }^{3}$, Letícia Kimura ${ }^{4}$, Fábio Martynetz ${ }^{4}$, Michele Lemos ${ }^{4}$
}

Biondo-Simões MLP, Ioshii SO, Kimura L, Martynetz F, Lemos M, Borsato KS. Effect of aging on the healing of colonic anastomoses in rats. Acta Cir Bras [serial online] 2004 Mar-Apr;19(2). Available from URL: http://www.scielo.br/ acb.

ABSTRACT - Purpose: To evaluate the healing of the colonic anastomoses in old and young adult rats. Methods: Fifty six Wistar rats were allocated in two groups, the young animals aged on average 110 days and the old animals aged average 762 days. Under anesthesia, the rats underwent a midline laparotomy and the colon was sectioned $2 \mathrm{~cm}$ above the peritoneal deflection. An end-to-end interrupted one layer colonic anastomosis was performed and the animals sacrificed on the $3^{\text {rd }}, 7^{\text {th }}, 14^{\text {th }}$ and $21^{\text {st }}$ postoperative days. A $4 \mathrm{~cm}$ segment of colon containing the anastomosis was submitted to bursting pressure tests. The paraffin-embedded tissue blocs were sectioned and stained with haematoxylin and eosin and Sirius Red. Histochemical methods such as PCNA, LCA and CD34 were also used. Results: The colonic anastomosis resistance was greater in the old rats group on the $3^{\text {rd }}$ postoperative day $(\mathrm{p}=0,0000)$. Collagen concentration was higher in the anastomosis of the young animals on the $14^{\text {th }}$ and $21^{\text {st }}$ postoperative days ( $p=0,0475, p=0,0346$ respectively), with a significantly greater concentration of collagen type I. The concentration of collagen type III, the epithelial lining rate and the angiogenesis were similar in the study groups. Conclusion: Despite some differences between the two groups regarding the healing process and considering that failures in the colonic anastomosis wound healing could not be demonstrated, we can concluded that aging itself does not interfere in the wound healing process.

KEY WORDS - Colon. Wound healing. Aging.

\section{Introduction}

The progress in medicine has led to a better understanding of the health-disease relationship, and technological advances have permitted more precise diagnoses and more efficient therapies, with the work of public health services and information of the population leading to prevention of diseases. As a result, health conditions have improved and humans are living longer ${ }^{1,2}$, a fact that has led to an increase in the number of elderly individuals in hospitals ${ }^{3}$.

Surgical procedures carried out in elderly patients raise concern on the part of doctors and relatives regarding possible complications. Some authors believe that age is not a factor predisposing to complications $^{4}$, while others have demonstrated that complications in elderly patients definitely lead to higher rates of morbidity and mortality ${ }^{3,5-9}$.

Schrock et $\mathrm{al}^{10}$ observed a larger number of dehiscences of colon anastomoses in individuals older than 60 years $(\mathrm{p}<0.05)$, which increased even further in patients aged 80 years or older $(\mathrm{p}<0.01)$. Gottrup ${ }^{11}$ has demonstrated that the concentration of collagen was higher in gastric wounds of older animals than in younger animals, while in duodenal wounds this concentration was similar.

Petersen et al ${ }^{12}$ reported that the resistance of colonic anastomotic wounds was the same in old and young rats, although the collagen concentration was lower in the anastomoses of old animals. Stoop et al ${ }^{13}$ found a higher resistance and higher collagen concentration in the anastomoses of old rats 7 days after surgery.

Few experimental studies are available regarding the effect of aging on the cicatricial response. Therefore, the objective of the present study was to monitor the healing of colonic anastomoses in old rats.

\section{Methods}

The present investigation was carried out according to the norms on animal research laid down by Federal Law 6.638 and to the criteria of the Brazilian College of Animal Experimentation, an institution affiliated with the International Council for Laboratory Animal Science, and was approved by the Ethics Committee on Animal Research of Pontific Catholic University of Parana (PUCPR).

1. Study carried out at the Discipline of Surgical Technique and Experimental Surgery, Medicine Course, Pontific Catholic University of Paraná (PUCPR)

2. MD, Coordinator, Discipline of Surgery Technique and Experimental Surgery, Department of Surgery, Faculty of Medicine, Federal University of Parana (UFPR) and Professor, Pontific Catholic University of Parana (PUCPR).

3. MD, Assistant Professor, Discipline of Experimental Pathology, PUCPR.

4. Scientific Initiation Student, Discipline of Surgical Technique and Experimental Surgery, Medicine Course, PUCPR. 
Fifty-six male Wistar-TECPAR rats (Rattus norvegicus albinus, Rodentia mammalia) were divided into two groups of 28 animals each: one consisting of young rats aged 100 to 113 days and weighing 185 to $220 \mathrm{~g}$ ( group J), and one consisting of old rats aged 750 to 776 days and weighing 270 to $380 \mathrm{~g}$ (group V).

The animals were housed in cages appropriate for the species at the Animal House of PUCPR under natural light/dark and humidity conditions at a controlled temperature of $20 \pm 2^{\circ} \mathrm{C}$, with free access to rat chow and water throughout the experiment.

After cleaning the colon, the ventral abdominal wall was depilated and disinfected with polyvinylpyrrolidone iodide under ethyl ether inhalation anesthesia. A 4-cm median incision was made and a transverse colotomy was carried out $2 \mathrm{~cm}$ from the peritoneal reflexion. The animals were then submitted to end-to-end anastomosis on a single extramucosal plane of synthesis using eight 6.0 nylon monofilament stitches. After laparorrhaphy and recovery from anesthesia, the animals were returned to their cages where they remained until the day of the measurements.

Seven animals of each group were selected by drawing lots for sacrifice on postoperative days 3, 7, 14 and 21 by inhalation of an ether overdose (Young groups = J.3, J.7, J.14 and J.21) ( Old groups = V.3, V.7, V.14 and V.21) At autopsy, $4 \mathrm{~cm}$ of the colon containing the anastomosis was removed, with care being taken not to detach its adhesions, and this segment was submitted to manometric analysis. The colon segment was opened and the specimen stretched out on a filter paper strip was fixed in buffered formalin and embedded, and the blocks were cut into $4-\mu \mathrm{m}$ sections. Five slides containing three sections each were prepared and submitted to five different staining techniques: hematoxylin-eosin, Sirius red histochemical staining, and immunohistochemistry using leukocyte common antigen (LCA), primary monoclonal antibodies against proliferating cell nuclear antigen (PCNA) and anti-CD34. The following general aspects were then analyzed: collagen deposition, inflammatory reaction, cell proliferation, and neovascularization.

The results were analyzed statistically by the chi-square test for $2 \times 2$ tables, or the

Fisher exact test when restrictions were present. Data were compared by the Student t-test, or the Mann-Whitney test when the results did not show a Gaussian distribution. In all cases, a p value $=0.05$ or $5.0 \%$ was established for rejection of the null hypothesis.

\section{Results}

Material from two young rats and one old rat was lost during preparation.

\section{Macroscopic analysis}

No dehiscences, abscesses or peritonitis were observed. Adhesions were present

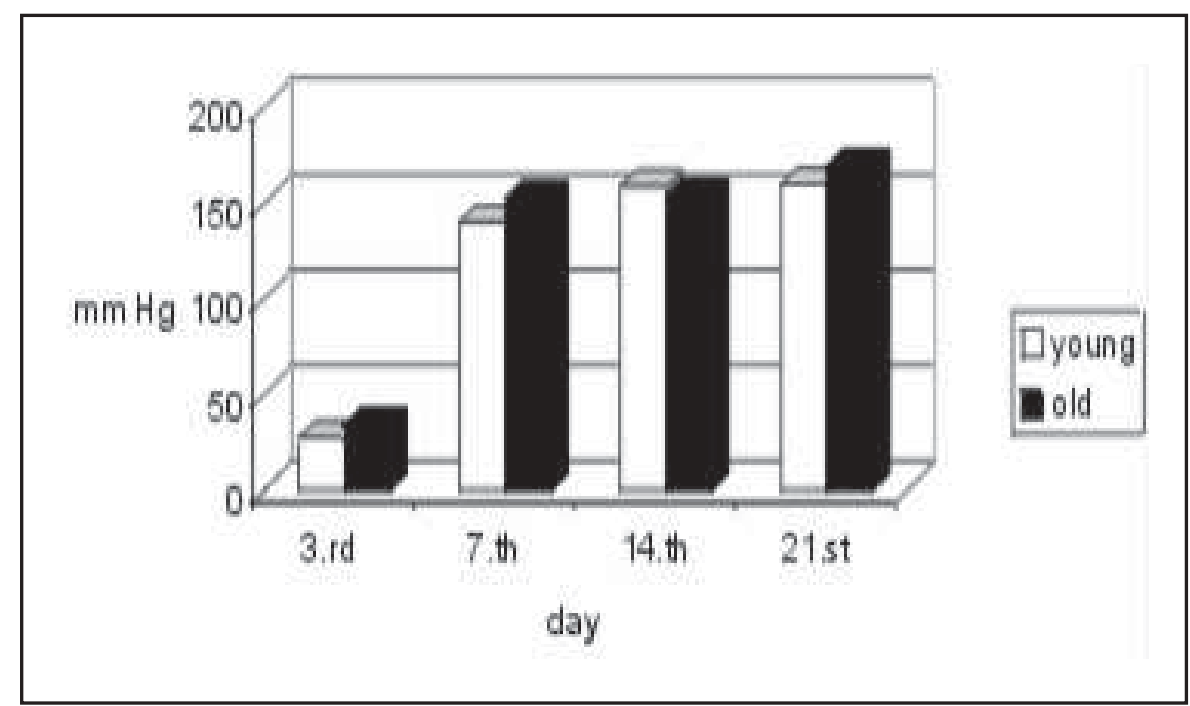

FIGURE 1 - Resistance gain of the colonic anastomoses in young and old rats at the four time points studied $\left(\mathrm{p}_{3}=0.0639, \mathrm{p}_{7}=0.1904, \mathrm{p}_{14}=0.4015, \mathrm{p}_{21}=0.3467\right)$.

\section{Microscopic analysis}

Analysis of the hematoxylin-eosin-stained histological sections showed a similar general evolution of the colon anastomoses in young and old rats. On day 3 , solution of continuity was observed for all intestinal wall layers, except for the peritoneum where adhered adipose tissue was noted. The internal spur presented areas of coagulative necrosis, and fibrin and inflammatory cells were observed on its surface. The area between the margins of the lesion was found to be infiltrated by inflammatory cells and marginal reepitelialization was present. On day 7, reepitelialization was intense and fibroblast infiltrates and

in 23 of the 26 anastomoses of adult young animals and in 23 of 27 anastomoses of adult old rats $(\mathrm{p}=0.05219)$.

\section{Anastomotic resistance}

The colon segments submitted to manometry showed a minimum capacity to withstand pressure on day 3 for both groups, which then increased over time. The resistance gain of the anastomoses was similar for the two groups (Figure 1). It is interesting to note that the colons ruptured along the anastomotic line on day 3 and outside this line at the other time points studied. 


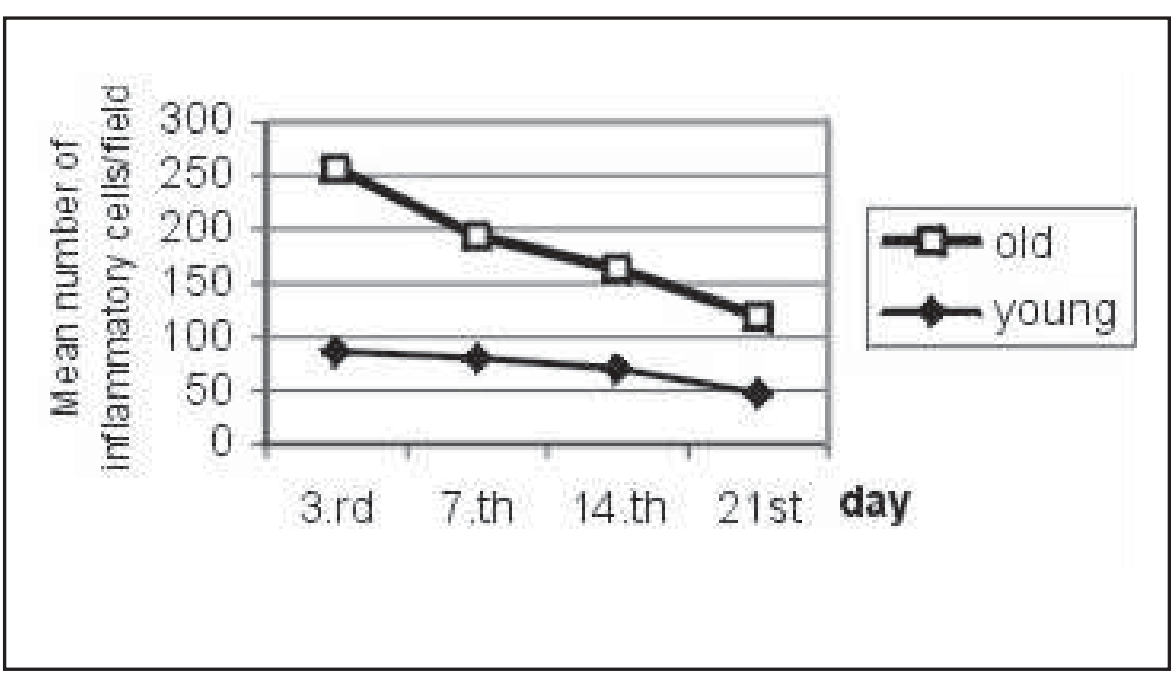

FIGURE 2 - Inflammatory cell concentration in the anastomoses of young and old rats at the four time points studied $\left(\mathrm{p}_{3}=0.0000, \mathrm{p}_{7}=0.0130, \mathrm{p}_{14}=0.0130, \mathrm{p}_{21}=0.1650\right)$.

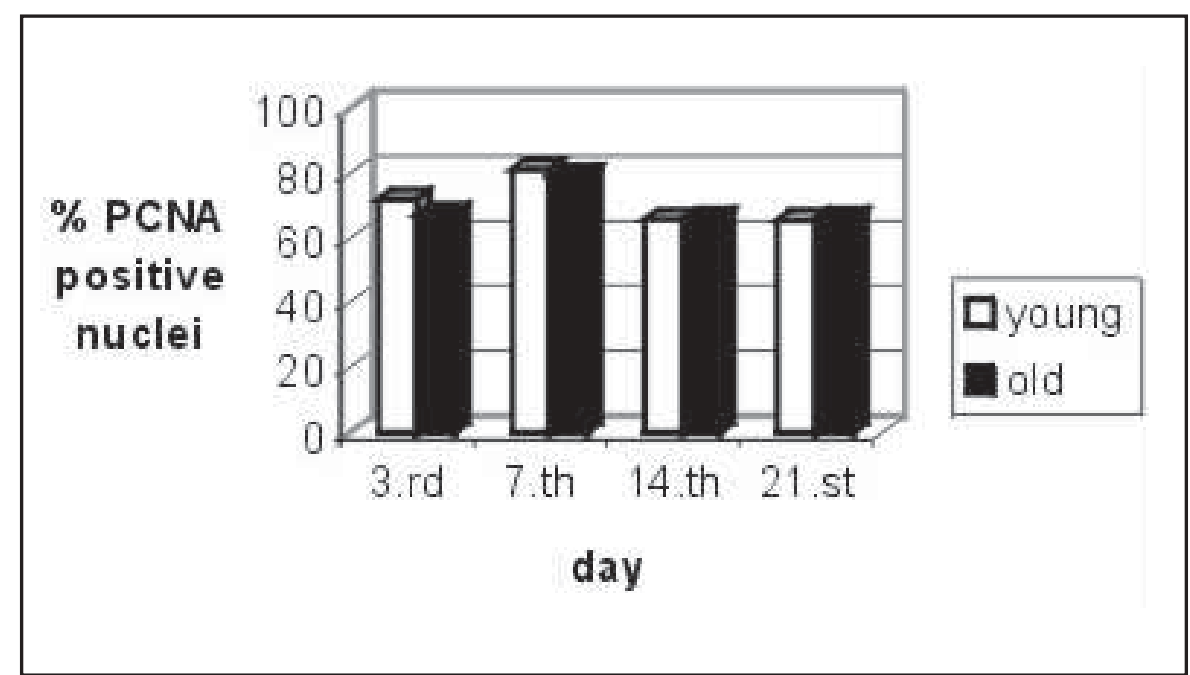

FIGURE 3 - Percentage of PCNA-positive nuclei in histological sections of the glandular epithelium obtained from colon anastomoses of young and old rats at the four time points studied $\left(\mathrm{p}_{3}=0.1484\right.$, $\left.\mathrm{p}_{7}=0.2017, \mathrm{p}_{14}=0.4509, \mathrm{p}_{21}=0.3956\right)$.

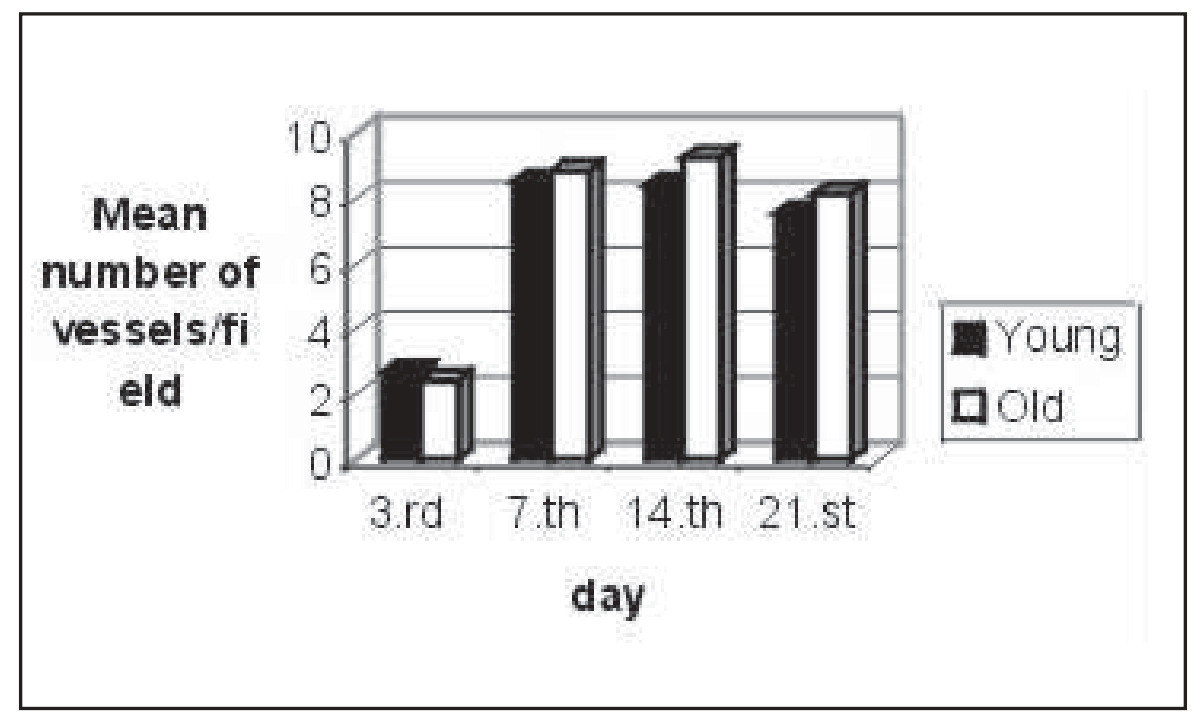

FIGURE 4 - Evolution of angiogenesis observed in histological sections obtained from the anastomoses of young and old rats at the four time points studied $\left(\mathrm{p}_{3}=0.2151, \mathrm{p}_{7}=0.3675, \mathrm{p}_{14}=0.1900\right.$, $\left.\mathrm{p}_{21}=0.2625\right)$.
Immunohistochemical analysis using the anti-CD34 antibody permitted the assessment of angiogenesis. The mean number of vessels per field was similar for the anastomoses of the two groups (Figure 4).

In order to obtain the mean percent area occupied by collagen, three histological sections stained with Sirius red were analyzed under polarized light. A lower collagen concentration was observed on day 3 , which increased along time. A similar collagen concentration was observed on days 3 and 7 for the anastomoses of young and old rats, while on days 14 and 21, the colon anastomoses of young rats contained more collagen than those of old rats. Determination of the percentage of collagen III, represented by fine and green fibers, in the anastomotic wounds showed similar concentrations for young and old animals at all time points studied. In contrast, the collagen I concentration, represented by thick and reddish fibers, was higher in the anastomoses of young rats on day $14(\mathrm{p}=0.0076)$ and day $21(\mathrm{p}=0.0067)$ (Figure 5).

\section{Discussion}

Anastomoses in the digestive tract have generally been reported to evolve without major complications ${ }^{11-14}$. In the present study, neither young nor old animals developed dehiscence.

Gottrup ${ }^{11}$, analyzing the resistance of gastrorrhaphies and duodenorrhaphies on days 7 and 20 after surgery, observed a similar resistance of the anastomoses in old and young rats ${ }^{11}$.

Petersen et al ${ }^{12}$ did not observe any difference in left colon anastomoses on day 2 or 4 between young and old rats. Stoop et $\mathrm{al}^{13,14}$ found that on day 3 after surgery anastomoses were more resistant in old animals, while on day 7 a similar resistance was observed for old and young animals. In the present study, resistance of the anastomoses was similar for young and old animals during the early as well as during the late postoperative period, i.e., day 14 and day 21 . It is interesting to note that on day 3 the colons ruptured along the anastomotic line, while at the other time points studied, ruptures occurred outside this line. The withstood pressure was also minimal on day 3 , a fact 
that, together with the site of rupture, suggests that irrespective of the age of the animals the anastomoses are fragile during this period and that the integrity of colonic transit is maintained by the presence of the suture.

All studies reported in the literature refer to the inflammatory phase of healing from

a qualitative rather than a quantitative point of view. In the present study, leukocyte labeling showed significantly higher cell infiltration in old animals, especially on day 3 after surgery. However, although a stronger inflammatory reaction was observed, it did not impair the evolution of these anastomoses.

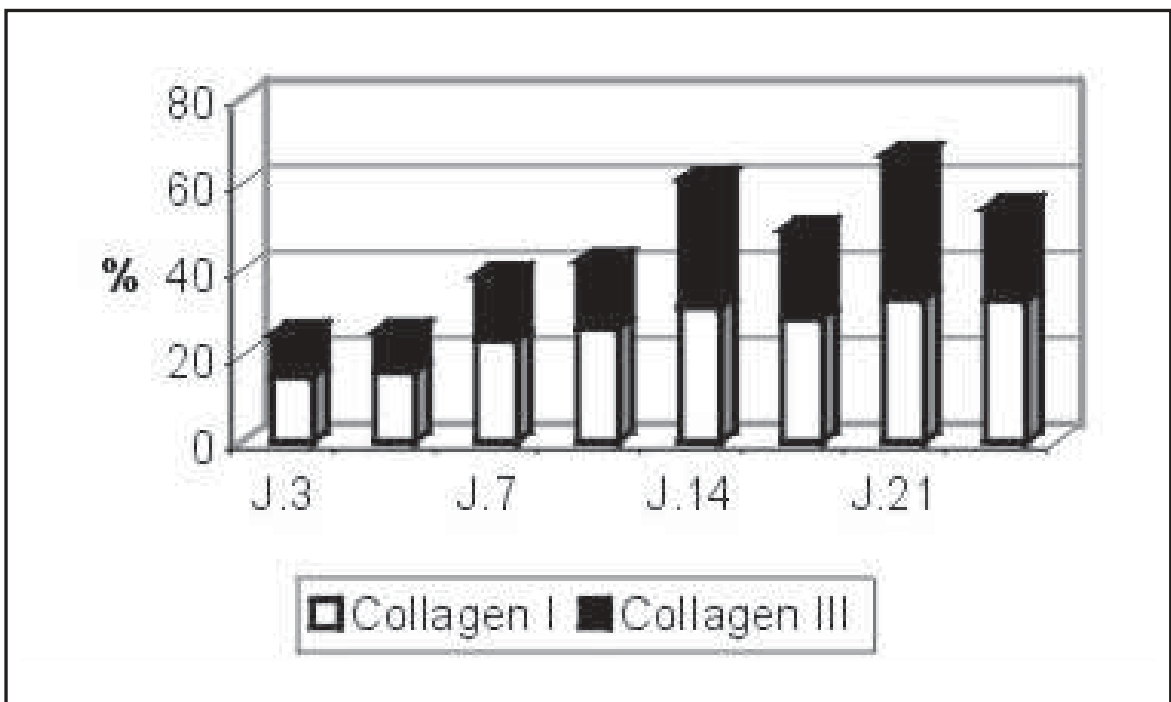

FIGURE 5 - Mean percent collagen content in histological sections obtained from the anastomoses of young and old rats. Total collagen ( $\mathrm{t}$-test; $\mathrm{p}_{3}=0.05427, \mathrm{p}_{7}=0.2069, \mathrm{p}_{14}=0.0475, \mathrm{p}_{21}=0.0346$ ).

Reepithelialization is part of the healing process and represents an important division between intraluminal content and intestinal wall tissue. Analysis of PCNApositive cells at the four time points studied showed a similar course of epitelialization for the two groups, as indicated by the same replication intensity of surface and crypt base nuclei and the disappearance of the solution of continuity between the intestinal wall and lumen within the same time interval in the anastomoses of old and young animals.

Like epithelialization, angiogenesis has not been studied by other authors analyzing the healing process of anastomoses in old animals. In the present study, determination of the number of vessels per field did not reveal any effect of aging on angiogenesis.

Gottrup $^{11}$ demonstrated a higher collagen content in the gastric and duodenal wounds of old animals $(\mathrm{p}<0.01)$ both on day 7 and day 20. Stoop et $\mathrm{al}^{13}$ observed the same for colon anastomoses $(p=0.0001)$. In the present study, the collagen content of the anastomoses was similar for old and young animals during the early postoperative period, while a higher collagen content was observed for young animals on days 14 and 21 $\left(\mathrm{p}_{14}=0.0475, \mathrm{p}_{21}=0.0346\right)$. It is interesting to note that this difference was due to a higher concentration of collagen type I in these wounds, suggesting faster wound maturation in the anastomoses of young animals. Nevertheless, since the capacity to withstand pressure was similar for the two groups, the amount of collagen present in the wounds of old animals was apparently sufficient to confer resistance to the anastomoses.

Based on the present results it seems likely that, at least in rats, age does not represent a risk factor for the healing of colon anastomoses.
Although a larger inflammatory cell infiltrate and lower collagen concentration can be observed in older rats, left colon anastomoses show a similar clinical evolution in old and young animals.

\section{References}

1. Reiss R, Deutsch AA, Nudelman I. Surgical problems in octogenarians: epidemiological analysis of 1083 consecutive admissions. World J Surg 1992; 16:1017-21.

2. Kinsella K. Dimensiones demográficas y de salud en America Latina y el Caribe. In: Péres AE, Galinsky D, Martínez FM, Salas AR, Ayéndez MS. La atención de los ancianos: un desafio para los años noventa. Washington DC: OPS; 1994. p.3-18.

3. Bufalari M, Ferri M, Lolli G, Fabri C, Bisacci R. La chirurgia generale nel paziente ottuagenario. Minerva Chir 1996; 51:383-8.

4. Montesani C, De Milito R, Chiappolone S, Narilli P, D'Amato A, Ribotta G. Critical evaluation of the anastomoses in large bowel surgery: experience gained in 533 cases. Hepatogastroenterology 1992; 39:304-8.

5. Greenburg AG, Salk RP, Pridham D. Influence of age on mortality of colon surgery. Am J Surg 1985; 150:65-70.

6. Conti A, Tonini V. Mortalità e morbilità postoperatoria negli ultraottantenni. Minerva Chir 1991; 46:867-73.

7. Lubin MF. Is age a risk factor for surgery? Med Clin North Am 1993; 77:327-33.

8. Hirsch $\mathrm{CH}$. When your patients needs surgery: weighing risks versus benefits. Geriatrics 1995; 50:26-31.

9. Souza Filho ZA. Avaliação do risco cirúrgico em octogenários [Tese - Professor Titular]. Faculdade de Medicina da Pontifícia Universidade Católica do Paraná; 2000.

10. Schrock TR, Deveney CW, Dunphy JE. Factors contributing to leakage of colonic anastomoses. Ann Surg 1973; 177:513-8.

11. Gottrup F. Healing of incisional wounds in stomach and duodenum:t he influence of aging. Acta Chir Scand 1981; 147:363-9.

12. Petersen TI, Kissmeyer-Nielsen P, Laurberg $\mathrm{S}$, Christensen $\mathrm{H}$. Impaired wound healing but unaltered colonic healing with increasing age: an experimental study in rats. Eur Surg Res 1995; 27:250-7.

13. Stoop MJ, Dirksen R, Hendriks T. Advanced age alone does not suppress anastomotic healing in the intestine. Surgery 1996; 119:15-9.

14. Stoop MJ, Dirksen R, Wobbes T, Hendriks T. Effects of early postoperative 5-fluoracil and ageing on the healing capacity of experimental intestinal anastomoses. $\mathrm{Br} \mathrm{J}$ Surg 1998; 85:1535-8. 
Biondo-Simões MLP, Ioshii SO, Kimura L, Martynetz F, Lemos M, Borsato KS. Efeitos do envelhecimento na cicatrização de anastomoses colônicas em ratos. Acta Cir Bras [serial online] 2004 Mar-Abr;19(2). Disponível em URL: http://www.scielo.br/acb.

RESUMO - Objetivo: Avaliar a cicatrização de anastomoses colônicas em ratos adultos, jovens e velhos. Métodos: Cinquenta e seis ratos machos, Wistar foram alocados em dois grupos, um de animais adultos jovens com idade media de 110 dias e outro de animais velhos, com idade media de 762 dias. Sob anesthesia os ratos forma submetidos a uma laparotomia mediana e o cólon foi seccionado $2 \mathrm{~cm}$ acima da reflexão peritoneal. Uma anastomose términoterminal foi feita e avaliada após 3, 7, 14 e 21 dias. Nestas datas após a euthanasia e laparotomia, um segmento de 4 $\mathrm{cm}$ do colon que continha a anastomoses foi ressecado e submetido a teste manométrico para verificação da resistência à pressão. Após os segmentos, emblocados em parafina, foram seccionados fornecendo cortes que foram corados pela hematoxilina e eosina e pelo Sirius red. Métodos histoquímicos como PCNA, LCA e CD 34 foram utilizados para a verificação da reepitelização, reação inflamatória e angiogênese. Resultados: A resistência das anastomoses foi maior nos animais velhos no $3 .^{\circ}$ dia de pós-operatório $(\mathrm{p}=0,0000)$. A concentração de colágeno foi maior nas anastomoses dos animais jovens no $14 .^{\circ}$ e no $21{ }^{\circ}$ dia de pós-operatório ( $\mathrm{p}=0,0475, \mathrm{p}=0,0346$ respectivamente), com significante concentração de colágeno tipo I. A concentração do colágeno tipo III, a taxa de reepitelização e de angiogênese foi similar nos dois grupos de estudo. Conclusão: Apesar de algumas diferenças entre os dois grupos no que se refere ao processo de cicatrização deiscências não foram vistas o que permite concluir que a idade por si só não é suficiente para modificar a cicatrização.

DESCRITORES - Cólon. Cicatrização de feridas. Envelhecimento.

Correspondence:

Maria de Lourdes Pessole Biondo-Simões

Rua Ari José Valle, 1987

82030-000 Curitiba - PR

Tel/Fax: (41)297-4359

biondo@avalon.sul.com.br

Conflict of interest: none

Financial source: none

\author{
biondo@avalon.sul.com.br
}

Data do recebimento: $18 / 11 / 2003$

Data da revisão: 05/12/2003

Data da aprovação: 05/01/2004 